
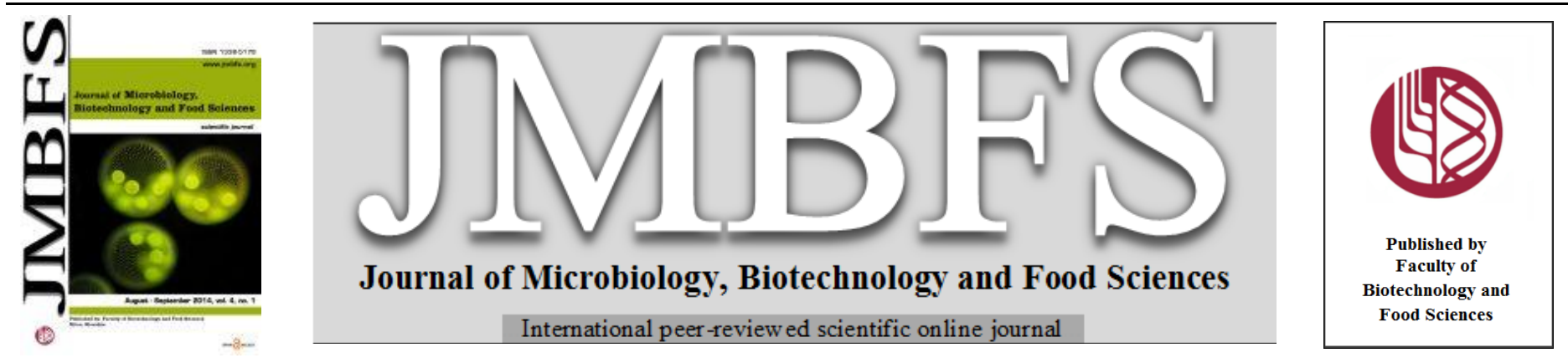

\title{
ZYMOGRAPHIC IDENTIFICATION AND BIOCHEMICAL CHARACTERIZATION OF CHITINASE AGAINST PHYTOFUNGAL PATHOGENS
}

\author{
Urja Pandya ${ }^{l}$,Ankit Sudhir ${ }^{2}$, Hardik Gohel $^{3}$, R.B. Subramanian ${ }^{2}$, Meenu Saraf $^{1 *}$ \\ Address(es): \\ ${ }^{\mathbf{1} D e p a r t m e n t ~ o f ~ M i c r o b i o l o g y ~ a n d ~ B i o t e c h n o l o g y, ~ U n i v e r s i t y ~ S c h o o l ~ o f ~ S c i e n c e s, ~ G u j a r a t ~ U n i v e r s i t y, ~ A h m e d a b a d ~ 380009, ~ G u j a r a t, ~ I n d i a . ~}$ \\ ${ }^{2}$ BRD School of Biosciences, Sardar Patel University, Satellite Campus, Sardar Patel Maidan, Vadtal Road, PO Box 39 , Vallabh Vidyanagar 388 120, Gujarat, India. \\ ${ }^{3}$ Loyola Centre for Research and Development, St. Xavier's college, Navaragnpura, Ahmedabad 380 009, Gujarat, India.
}

*Corresponding author: sarafmeenu@gmail.com

doi: 10.15414/jmbfs.2014.4.1.44-47

\section{ARTICLE INFO}

Received 12. 2. 2014

Revised 28. 5. 2014

Accepted 9. 7. 2014

Published 1. 8. 2014

Regular article

OPEN $\partial_{\text {ACCESS }}$

\section{ABSTRACT}

An endospore forming Gram positive bacterium (MBCU4) was isolated from a vermicompost amended soil, and confirmed as Bacillus subtilis through the 16S rRNA sequence analysis. An extracellular chitinase was detected from this strain of $B$. subtilis under specific environmental condition. An attempt was made to purify the enzyme by ammonium sulfate precipitation followed by DEAE sepharose CL-6B column chromatography. The purified enzyme was demonstrated as a single band, having the molecular weight 31kDa on SDS PAGE analysis and its activity in the gel was determined by clear zone on zymogram. Further characterization of the isolated enzymes has showed that this enzyme is most active at $\mathrm{pH} 6.0$ and at the optimized temperature of $50{ }^{\circ} \mathrm{C}$. The purified chitinase exhibited high degree of antifungal activity particularly by degrading their cell wall components of plant pathogens Macrophomina phaseolina (69.0\%) and Rhizoctonia solani (52.0\%). It infers that the chitinase produced by B. subtilis could play an important role for biopesticidal activity.

Keywords: Antifungal, Bacillus subtilis, Biocontrol, Chitinase, Zymography

\section{INTRODUCTION}

The endospore forming genus Bacillus is one of the most widely researched and commercialized biocontrol agents (Paulitz and Belanger, 2001). Their biocontrol mechanisms include production of antibiotics and extracellular hydrolytic enzymes such as chitinase, laminarinase, lipase, and protease. These hydrolase enzymes contribute to degradation of fungal cell wall (Korsten $\boldsymbol{e t}$ al., 1993; Paulitz and Belanger, 2001; Helisto et al., 2001) thus suitable for control of phyopathogenic fungi. Among those hydrolases chitinases considered as key hydrolytic enzymes in the lysis of cell walls of fungi, and play important factors in biological control (Guthrie et al., 2005). Chitinases (E.C. 3.2.1.14.) are enzymes that are capable of hydrolyzing chitin to its oligomers and/or monomers. Chitinase from various origins has different enzymological properties and usually constitutes a complex chitinolytic enzyme. These enzymes play an important role in the nutrition and parasitism of bacteria and fungi. Identification and characterization of chitinase are prerequisites for understanding their role in the pathogenesis of infectious diseases as well as to improve their application in biotechnology. Zymography in protein chemistry provides reliable identification of enzymes like chitinase, based on the molecular mass of their active forms after gel electrophoresis (Grudkowska $\boldsymbol{e t}$ al., 2013). It is based on visualization of areas where the specific substrate is digested by the enzyme of interest. It can be used to perceive the total enzymatic activity or to see activities of enzyme isoforms following the protein electrophoretical separation on polyacrylamide gels (Vandooren et al., 2013). The present study attempts to identify and characterize chitinase from newly isolated $B$. subtilis MBCU4 using zymography technique to enhance resolution and for molecular size determination, and evaluate the antifungal activities of the isolated chitinase against common fungal pathogens.

\section{MATERIAL AND METHODS}

\section{Identification of bacterial strains}

The bacterial strains used in this study were isolated from vermicompost amended site (fertile land of Dantiwada Agricultural University, Dantiwada district, Gujarat, India) as explained earlier (Pandya et al., 2014). They were screened on colloidal chitin agar plates (contains a semi minimal medium supplemented with $1 \%$ colloidal chitin) as explained by Sampson and Gooday
(1998). After incubating the plates at $30^{\circ} \mathrm{C}$ for five days, they were flushed with $1 \%$ Congo red solution for $10 \mathrm{~min}$ followed by washing with $1 \mathrm{M} \mathrm{NaCl}$. The zones of degradation of chitin became visible as translucent halos around the colonies. The colonies from the higher zone of chitinase activity were selected and maintained on minimal medium for retesting. Among the retested colonies, the most potent MBCU4 was selected for further study. The bacterial strain MBCU4 was preliminary identified as Bacillus subtilis on the basis of its morphological, physiological and biochemical parameters which were then confirmed by $16 \mathrm{~S}$ rRNA sequences. The sequence was submitted to NCBI and an accession number KC907389 was obtained.

\section{Purification of Chitinase}

Strain MBCU4 was cultured in $1000 \mathrm{ml}$ of semi minimal medium containing 1\% colloidal chitin at $37{ }^{\circ} \mathrm{C}$ for $48 \mathrm{hrs}$. The supernatant was harvested by centrifugation at $4{ }^{\circ} \mathrm{C}$ for $20 \mathrm{~min}$ at $12,000 \mathrm{~g}$ and used for further purification using chromatography techniques. Column chromatography technique was used according to the modified method of Wang et al., (2012). Ammonium sulfate was added $(608 \mathrm{~g} / \mathrm{l})$ to the culture supernatant $(940 \mathrm{ml})$ and stored at $4{ }^{\circ} \mathrm{C}$ overnight. After centrifugation at $4{ }^{\circ} \mathrm{C}$ for $20 \mathrm{~min}$ at $12,000 \mathrm{~g}$, the precipitate was dissolved in a $0.5 \mathrm{ml}$ of $50 \mathrm{mM}$ sodium phosphate buffer $(\mathrm{pH} 7)$ and dialyzed against the same buffer. The resultant dialysate was loaded onto a DEAESepharose CL-6B column $(5 \mathrm{~cm} \times 30 \mathrm{~cm})$ equilibrated with $50 \mathrm{mM}$ sodium phosphate buffer $(\mathrm{pH} 7)$. The fractions containing the chitinase were individually collected and concentrated using ammonium sulfate. The resultant precipitates were collected by centrifugation and dissolved in $0.5 \mathrm{ml}$ of $50 \mathrm{mM}$ sodium phosphate buffer ( $\mathrm{pH} 7)$.

\section{Characterization and Zymogram studies}

The protein content was determined using the Bradford method with a Bio-Rad dye reagent concentrate and bovine serum albumin as the standard. After column chromatography, the protein concentration was estimated by measuring the absorbance at $280 \mathrm{~nm}$ (Wang $\boldsymbol{e t}$ al., 2006). Chitinase activity was measured with colloidal chitin as a substrate. Enzyme solution $(0.5 \mathrm{ml})$ was added to $1 \mathrm{ml}$ of substrate solution and $1.5 \%(\mathrm{w} / \mathrm{v})$ suspension of colloidal chitin in phosphate buffer $(50 \mathrm{mM}, \mathrm{pH} 7.0)$ and the mixture was incubated at $37^{\circ} \mathrm{C}$ for $15 \mathrm{~min}$. After centrifugation, the amount of reducing sugar produced in the supernatant was 
determined using $\mathrm{N}$-acetylglucosamine as a standard (Imoto and Yagishita, 1971). One unit (U) of chitinase was defined as the amount of enzyme that produced reducing sugars corresponding to $1 \mu \mathrm{mol}$ of $\mathrm{N}$-acetyl glucose-amine equivalents from colloidal chitin per minute under the assay conditions. The optimum $\mathrm{pH}$ for the chitinase activity was measured under standard assay conditions, using the following buffers (all at $50 \mathrm{mM})$ : citrate phosphate $(\mathrm{pH} 3.0$ $5.0)$, sodium acetate ( $\mathrm{pH} 5.0-6.0)$, sodium phosphate $(\mathrm{pH} 6.0-8.0)$, Tris- $\mathrm{HCl}(\mathrm{pH}$ 8.0-9.0), and carbonate-bicarbonate buffer ( $\mathrm{pH}$ 9.0-11.0). The optima temperature for the chitinase activities was determined by performing the condition assay (Prasanna et al., 2013) at temperatures ranging from 10 to 100 ${ }^{0} \mathrm{C}$. The molecular mass of purified chitinase was estimated by sodium dodecyl sulphate polyacrylamide gel electrophoresis (SDS-PAGE) using a $10 \%$ gel according to Laemmli (1970) method. The proteins were visualized by staining with Coomassie brilliant blue R-250. For zymogram analysis of chitinase, the protein samples were mixed with loading buffer without reducing agent and heating. After electrophoresis, the gel was incubated in $100 \mathrm{mM}$ sodium acetate buffer, $\mathrm{pH} 5$ at $40{ }^{\circ} \mathrm{C}$ for $18 \mathrm{~h}$. The activated chitinase on the gel was visualized by staining with $0.1 \%$ Congo red followed by de staining with $1 \mathrm{~N} \mathrm{NaCl}$ (Yamabhai et al., 2008).

\section{Antifungal properties of Chitinase}

Both crude and purified chitinase were tested for inhibitory activity against the fungal strains such as Macrophomina phaseolina, Rhizoctonia solani, Fusarium oxysporum, Sclerotium rofsii and Sclerotinia sclerotiorum. Spore suspensions of these fungi were prepared from 7 day old culture with sterile water, and $3 \mathrm{~m}$ suspension $\left(1 \times 10^{8}\right.$ spores $\left./ \mathrm{ml}\right)$ was seeded in $20 \mathrm{ml}$ of Potato Dextrose Agar (PDA). After 48h, about $200 \mu \mathrm{l}$ of cell-free culture filtrate of each fungal strain was added in three $8 \mathrm{~mm}$ wells of PDA. The treated plates were incubated at 28 ${ }^{0} \mathrm{C}$. The zone of inhibition on PDA was measured at different time intervals up to $72 \mathrm{hrs}$. The antifungal activity of chitinase was estimated using a growth inhibition assay described by Wang et al., (1999).

\section{RESULTS AND DISCUSSION}

\section{Identification of chitinolytic bacterium}

Many biocontrol agents from Bacillus and Pseudomonas have ability to produce chitinase and digest chitin as a source of carbon and energy (Xiao et al., 2009, Wang et al., 1997). Application of vermicompost as a biofertilizer can provide available nutrients to improve the productivity and control of soil borne fungal pathogens by the specific bacterial flora like Bacillus, Strptomyces, Aeromonas, Lysobacter and Salinispora spp. that showed important role in the environmental degradation of chitin (Xiao et al., 2005; Yasir et al., 2009). In the present study, our isolate MBCU4 showed a strong chitinolytic ability on agar medium containing $1 \%(\mathrm{w} / \mathrm{v})$ colloidal chitin, showing clear zone of inhibition around the colonies after 3 days of incubation at $30{ }^{\circ} \mathrm{C}$. The isolated strain was observed as a Gram positive rod shaped bacterium. On the basis of the nucleotide sequences of 16S rRNA gene, the bacterium was identified as Bacillus subtilis (Fig. 1).

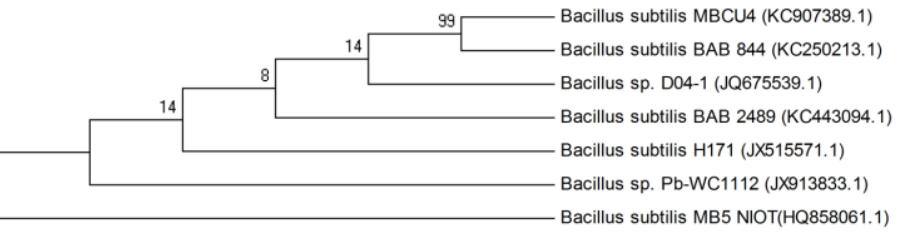

Figure 1 Phylogenetic analysis based on 16S rRNA gene sequences of newly isolated B. subtilis MBCU4 compared with other available B. subtilis strains from the European Molecular Biology Laboratory data library constructed after multiple alignments data by Clustal $X$. Distances and clustering with the neighbor-joining method was performed by using the software packages Mega version 4.0 .

\section{Purification of chitinase}

The isolate MBCU4 released chitinase into the culture broth showed specific activity of chitinase as $0.25 \mathrm{unit} / \mathrm{mg}$ protein with a purification factor of 2.08 (Table 1). Since, Chitinolytic zymogram analysis has been proved as one of the best detection techniques for the detection of active chitinase by substrate gel and imprint techniques was employed in the present study (Trudel and Asselin, 1990; Tronsmo and Harman, 1993). The resolution of zymogram is determined by the Laemmli condition of electrophoresis (Laemmli, 1970). The deviations of chitinolytic zymography-estimated molecular masses and calculated molecular masses of chitinases were calculated as reported earlier (Pechsrichuang $\boldsymbol{e t}$ al., 2013; Songsirittigul et al., 2010). Our chitinolytic zymography assay used in this study revealed a high resolution, excellent linearity, and range of calibration to determine molecular masses of chitinases. Our results showed presence of single zymographic band, which had molecular weight of $31 \mathrm{kDa}$ (Fig. 2). In a similar study, purified chitinase from sequential chromatography showed $31 \mathrm{kDa}$ of chitinase from B.subtilis (Yan et al., 2011; Chang et al., 2010).

\begin{tabular}{lccccc} 
Table 1 Purification of chitinase from B. subtilis (MBCU4) & & \\
\hline Purification step & $\begin{array}{c}\text { Total } \\
\text { protein } \\
\text { (mg) }\end{array}$ & $\begin{array}{c}\text { Total } \\
\text { activity } \\
\text { (U) }\end{array}$ & $\begin{array}{c}\text { Specific } \\
\text { activity } \\
\text { (U/mg) }\end{array}$ & $\begin{array}{c}\text { Purification } \\
\text { factor }\end{array}$ & $\begin{array}{c}\text { Yield } \\
\text { (\%) }\end{array}$ \\
\hline $\begin{array}{l}\text { Crude enzyme } \\
\text { (supernatant) }\end{array}$ & 1083 & 138 & 0.12 & 1.00 & 100.00 \\
\hline $\begin{array}{l}\text { 80\% Ammonium } \\
\text { sulfate precipitation }\end{array}$ & 898 & 121 & 0.14 & 1.17 & 87.61 \\
\hline $\begin{array}{l}\text { DEAE- Sepharose } \\
\text { CL-6B } \\
\text { chromatography }\end{array}$ & 57.85 & 14.37 & 0.25 & 2.08 & 10.41 \\
\hline
\end{tabular}

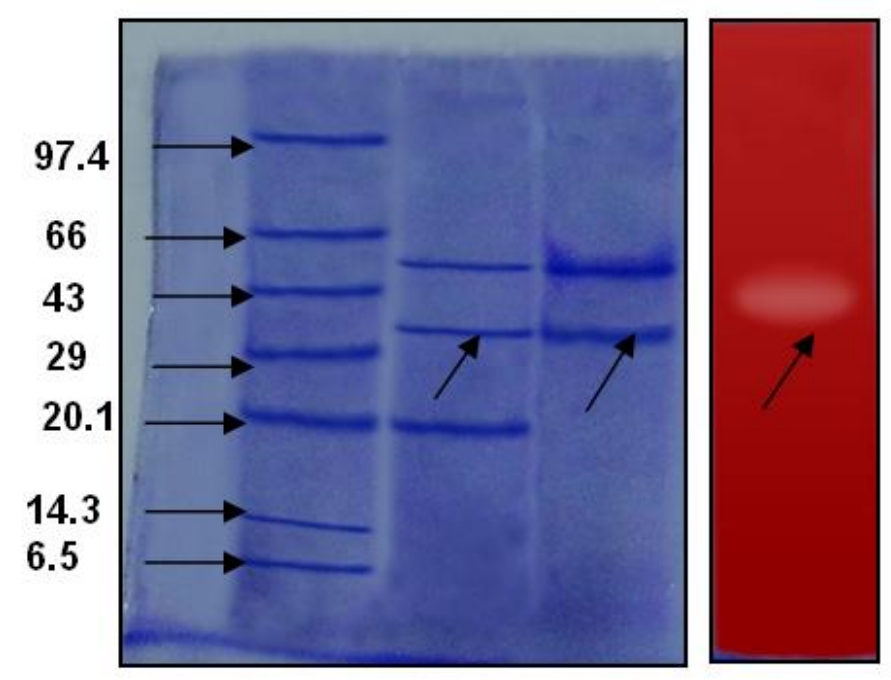

Figure 2 SDS PAGE and zymogram analysis of activated chitinase from stain B. Subtilis MBCU4. Lanes: M, Molecular marker; 1, crude enzyme; 2, the adsorbed chitinase fractions after DEAE sepharose CL-6B chromatography; 3 , activated chitinase detection on zymogram analysis.

\section{Effect of $\mathrm{pH}$ and temperature}

The optimum $\mathrm{pH}$ for the enzyme activity was found to be 6.0 which suggested that the chitinase from our strain has near neural $\mathrm{pH}$ range (Fig. 3). Chitinase also works better at an acidic or near neutral $\mathrm{pH}$ as reported in other Bacillus spp., such as B. pumilus SG2 at pH 6.0 (Ghasemi et al., 2010) and B. cereus YQ308 at pH 7.0 (Chang et al., 2003). We observed $50 \%$ of enzymatic activity was lost at extremely low and high $\mathrm{pH}$. The optimal chitinase activity was observed at 40 ${ }^{0} \mathrm{C}$ to $60{ }^{\circ} \mathrm{C}$ while low activities were noticed in the ranges of $10{ }^{\circ} \mathrm{C}$ to $30{ }^{\circ} \mathrm{C}$ or 80 ${ }^{0} \mathrm{C}$ to $100{ }^{0} \mathrm{C}$ respectively. The optimal temperature was $50{ }^{0} \mathrm{C}$, above which chitinase activity decreased (Fig. 4). These results showed similarity with optimum temperature for maximum chitinase production by $B$. subtilis as reported earlier (Chang et al., 2010; Yan et al., 2011).

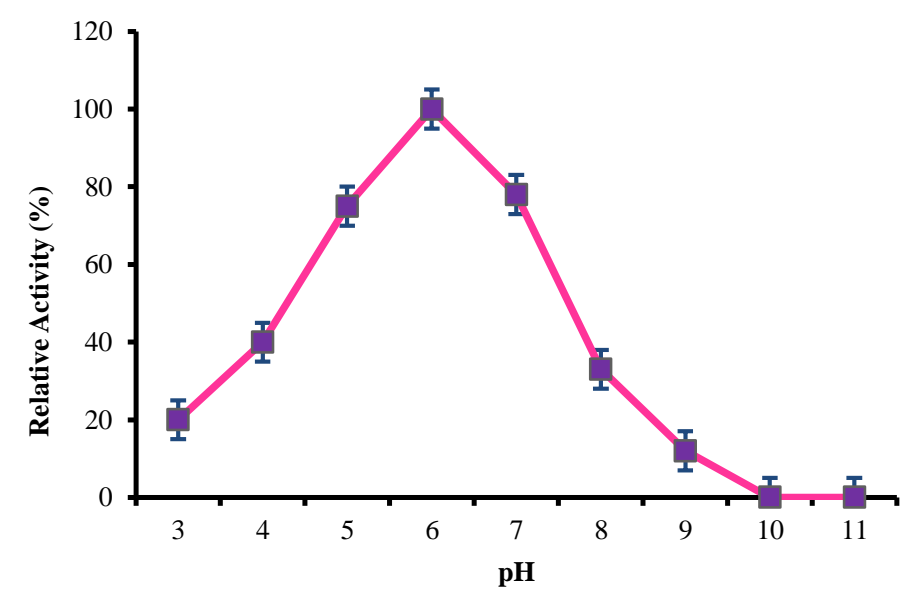

Figure 3 Effect of $\mathrm{pH}$ on relative activity of chitinase of newly isolated $B$ subtilis MBCU4 


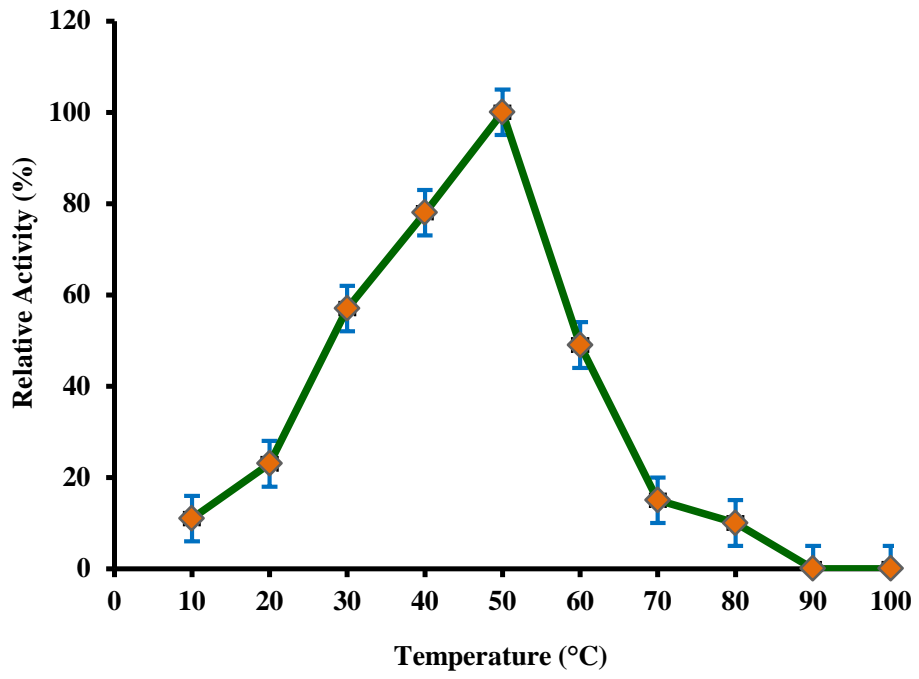

Figure 4 Effect of temperature on relative activity of chitinase of newly isolated B. subtilis MBCU4

\section{Antifungal activity of crude and purified chitinase}

An antifungal activity of purified chitinase was tested against five known fungal phytopathogens i.e. Macrophomina phaseolina, Rhizoctonia solani, Fusarium oxysporum, Sclerotium rofsii and Sclerotinia sclerotiorum. The purified chitinase of newly isolated B. subtilis MBCU4 was capable of suppressing the growth of two pathogens Macrophomina phaseolina and Rhizoctonia solani. Antifungal activity of crude and purified chitinase was also observed against $M$. phaseolina and $R$. solani (Table 2). The growth inhibition of $M$. phaseolina was the stronges both by crude and purified enzymes (78 and $69 \%$, respectively). The growth of $R$. solani was also inhibited by crude and purified chitinase (73 and 52\%). However, the growth of Fusarium oxysporum, Sclerotium rofsii and Sclerotinia sclerotiorum was only inhibited by crude chitinase. Chang et al., (2010) reported that purified chitinase from B. subtilis NPU 001 inhibited hyphal extension of $F$. oxysporum. Partially purified chitinases (ChiS and ChiL) from B. pumilus were tested against fungal phytopathogens such as Rhizoctonia solani, Verticillium sp., Nigrospora sp., Stemphyllium botryosum , Bipolaris sp., Phytophthora citricola and Phytophthora capsici under in vitro conditions. Results revealed that purified antifungal chitinase showed growth inhibition for all the pathogens except $P$. citrocola and P. capsici (Ghasemi et al., 2010). As reported earlier, B. pumilus SG2 secreted two chitinases which showed in vitro growth inhibition of the wheat pathogens $F$. graminearum and B. sorokiniana responsible for hyphal inhibitions of both the fungus in agar medium for a minimum 14 days (Shali et al., 2010).

Table 2 Antifungal activity of chitinase from $B$. subtilis MBCU4 against various phytopathogens

\begin{tabular}{lcc}
\hline \multirow{2}{*}{ Phytopathogens } & \multicolumn{2}{c}{ Antifungal Activity } \\
\cline { 2 - 3 } $\begin{array}{l}\text { Macrophomina } \\
\text { phaseolina }\end{array}$ & Crude chitinase & Purified chitinase \\
\hline Rhizoctonia solani & +++ & +++ \\
\hline Sclerotinia sclerotiorum & +++ & +++ \\
\hline Fusarium oxysporum & ++ & - \\
\hline Sclerotium rofsii & + & - \\
\hline
\end{tabular}

${ }^{a}$ Antifungal activity was classified as no inhibition (-; $\left.0 \%\right)$, moderate inhibition (+; 21-30

$\%)$, strong inhibition (++;31-50\%), and very strong inhibition (+++; $50 \%)$.

\section{CONCLUSION}

The newly isolated strain $B$. subtilis MBCU4 has better secretion capability for chitinase which could be used as a potential antifungal agent against plant fungal pathogens. The present study also revealed that zymography technique provides a sensitive, convenient, and inexpensive method for determination of activity of chitinase as employed in our newly isolated B. subtilis MBCU4. Further research to screen our purified chitinase from $B$. subtilis MBCU4 in vivo experiments against several other batteries of fungal pathogens will help to expand our studies.

Acknowledgments: The financial support from Department of Science and Technology (DST), New Delhi, India under Women Scientist Scheme (WOS-A) is gratefully acknowledged.

\section{REFERENCES}

CHANG, W.T., CHEN, C., WANG, S.L. 2003. An antifungal chitinase produced by $B$. cereus using shrimp and crab shell powder as a carbon source. Current Microbiology, 47,102-108. http://dx.doi.org/10.1007/s00284-002-3955-7

CHANG, W.T., CHEN, M.L., WANG, S.L. 2010. An antifungal chitinase produced by $B$. subtilis using chitin waste as a carbon source. World Journal of Microbiology and Biotechnology, 26, 945-950. http://dx.doi.org/10.1007/s11274009-0244-7

GHASEMI, S., AHMADIAN, G., JELODAR, N.B., RAHIMIAN, H. GHANDILI, S., DEHESTANI, Ali., SHARIATI, P. 2010. Antifungal chitinases from $B$. pumilus SG2: preliminary report. World Journal of Microbiology and Biotechnology, 26, 1437-1443. http://dx.doi.org/10.1007/s11274-010-0318-6

GRUDKOWSKA, M., LISIK, P., RYBKA，K. 2013. Two-dimensional zymography in detection of proteolytic enzymes in wheat leaves. Acta Physiologiae Plantarum, 35, 3477-3482. http://dx.doi.org/10.1007/s11738-0131371-1

GUTHRIE, J.L., KHALIF, S., CASTLE, A.J. 2005. An improved method for detection and quantification of chitinase activities. Canadian Journal of Microbiology, 51(6), 491-495. http://dx.doi.org/10.1139/w05-020

HELISTO, P., AKTUGANOV, G., GALIMZIANOVA, N., MELENTJIV, A., KORPELA, T. 2001. Lytic enzyme complex of an antagonistic Bacillus sp. x-b: isolation and purification of components. Journal of Chromatography B, 758 197- 205. http://dx.doi.org/10.1016/s0378-4347(01)00181-5

IMOTO, T., YAGISHITA, K. 1971. A simple activity measurement by lysozyme. Agricultural and Biological Chemistry, 35, 1154-1156. http://dx.doi.org/10.1271/bbb1961.35.1154

KORSTEN, L., De VILLIERS, E.E., WEIMER, F.C. et al. 1993. A review of biological control of postharvest diseases of subtropical fruits. Postharvest handling of tropical fruits. In: Proceedings of an international conference held at Chiang Mai, Thailand. Watson, Ferguson and Company, pp. 172-185.

LAEMMLI, U.K. 1970. Cleavage of structural proteins during the assembly of the head of bacteriophage T4. Nature 227, 680- 685 http://dx.doi.org/10.1038/227680a0

PANDYA, U., MAHESHWARI, D.K., SARAF, M. 2014. Assessment of ecological diversity of rhizobacterial communities in vermicompost and analysis of their potential to improve plant growth. Biologia,

PAULITZ, T.C., BELANGER, R. R. 2001. Biological control in greenhouse systems. Annual Reviews of Phytopathology, 39, 103-133. http://dx.doi.org/10.1146/annurev.phyto.39.1.103

PECHSRICHUANG, P., YOOHAT, K, YAMABHAI, M. 2013. Production of recombinant $B$. subtilis chitosanase, suitable for biosynthesis of chitosan oligosachharides. Bioresource Technology, 127, 407-414 http://dx.doi.org/10.1016/i.biortech.2012.09.130

PRASANNA, L., EIJSINK, V.G.H., MEADOW, R., GASEIDNES, S. 2010. A novel strain of Brevibacillus laterosporus produces chitinases that contribute to its biocontrol potential. Applied Microbiology and Biotechnology, 97, 1601-1611. http://dx.doi.org/10.1007/s00253-012-4019-y

SAMPSON, M.N., GOODAY, G.W. 1998. Involvement of chitinases of $B$. thuringiensis in insects. Microbiology, 144, 2189-2194. http://dx.doi.org/10.1099/00221287-144-8-2189

SHALI, A., GHASEMI, S., AHMADIAN, G., RANJBAR, G., DEHESTANI, Ali, KHALESI, N., MORTALlEBI, E., VAHED, M. 2010. B. pumilus SG2 chitinases induced and regulated by chitin, show inhibitory activity agains F.graminearum and B.sorokiniana. Phytoparasitica, 38, 141-147. http://dx.doi.org/10.1007/s12600-009-0078-8

SONGSIRIRITTHIGUL, C., LAPBOONRUENG, S., PECHSRICHUANG, P., PESATCHA, P., YAMABHAI, M. 2010. Expression and characterization of $B$ licheniformis chitinase (ChiA), suitable for bioconversion of chitin waste. Bioresource Technology, 101, 4096-4103. http://dx.doi.org/10.1016/j.biortech.2010.01.036

TRONSMO, A., HARMAN, G.E. 1993. Detection and quantification of Nacetyl- $\beta$-D-glucosaminidase, chitobiosidase, and endochitinase in solutions and on gels. Analytical Biochemistry, 208, 74-79. http://dx.doi.org/10.1006/abio.1993.1010

TRUDEL, J., ASSELIN, A. 1989. Detection of chitinase activity after polyacrylamide gel electrophoresis. Analytical Biochemistry, 178, 362- 366. http://dx.doi.org/10.1016/0003-2697(89)90653-2

VANDOOREN, J., GEURTS, J., MARTENS, E., VAN DEN STEEN, P. OPDENAKKER, P. 2013. Zymography methods for visualizing hydrolytic enzymes. Nature Methods, 10, 211-220. http://dx.doi.org/10.1038/nmeth.2371

WANG, S.L., LIN, T.Y., YEN, Y.H., LIAO, H.F., CHEN, Y.J. 2006 Bioconversion of shellfish chitin wastes for the production of B. subtilis W-118 chitinase. Carbohydrate Research, 341, 2507-2515. http://dx.doi.org/10.1016/j.carres.2006.06.027

WANG, S.L., YIEH, T.C., SHIH, I.L. 1999. Production of antifungal compounds by $P$. aeruginosa $\mathrm{K}-187$ using shrimp and crab shell powder as a carbon source. Enzyme and Microbial Technology, 25, 142-148. http://dx.doi.org/10.1016/s0141-0229(99)00024-1 
WANG, S.L., CHIO, S.H., CHANG, W.T. 1997. Production of chitinase from shell- fish wastes by $P$. aeruginosa K-187. Proceeding of National Science Council ROC(B), 21, 71-79. http://dx.doi.org/10.1016/s0141-0229(97)00264-0 WANG, S.L., LIU, C.P., LIANG, T.W. 2012. Fermented and enzymatic production of chitin/chitosan oligosaccharides by extracellular chitinases from Bacillus cereus TKU027. Carbohydrate Polymers, 90, 1305- 1313 http://dx.doi.org/10.1016/j.carbpol.2012.06.077

XIAO, L., XIE, C.C., CAI, J., LIN, Z.J., CHEN, Y.H. 2009. Identification and characterization of a chitinase produced Bacillus showing significant antifungal activity. Current Microbiology, 58, 528-533. http://dx.doi.org/10.1007/s00284009-9363-5

XIAO, X., YIN, X., LIN, J., SUN, L., YOU, Z., WANG, P., WANG, F. 2005

Chitinase genes in lake sediments of Ardley Island Antarctica. Applied and $\begin{array}{llll}\text { Environmental Microbiology, } & 71, & 7904-7909 .\end{array}$ http://dx.doi.org/10.1128/aem.71.12.7904-7909.2005

YAMABHAI, M., EMRAT, S., SUKASEM, S., PESATCHA, P., JARUSERANEE, N., BURANABANYAT, B. 2008. Secretion of recombinant Bacillus hydrolytic enzymes using Escherichia coli expression systems. Journal of Biotechnology, 133, 50-57. http://dx.doi.org/10.1016/j.jbiotec.2007.09.005

YAN, L., JING, T., YIJAN, Y., BIN, L., HUI, L., CHUN, L. 2011. Biocontrol efficiency of B.subtilis SL-13 and characterization of an antifungal chitinase. Chiense Journal of Chemical Engineering, 19(1), 128-134. http://dx.doi.org/10.1016/s1004-9541(09)60188-9

YASIR, M., ASLAM, Z., KIM, S.W., LEE, S.W., JEON, C.O., CHUNG, Y.R. 2009. Bacterial community composition and chitinase gene diversity of vermicompost with antifungal activity. Bioresource Technology, 100, 43964403. http://dx.doi.org/10.1016/j.biortech.2009.04.015 